\title{
Efektivitas Daun Singkong (Manihot esculenta) Var. Malang 1 Sebagai Pereduksi Kadar Formalin Pada Udang Putih (Pennaeus vannamei)
}

\section{Effectiveness Solution of Cassava Leaf (Manihot esculenta) Var. Malang 1 as Reducing Levels of Formalin in White Shrimp (Pennaeus vannamei)}

\section{Wirawan*, Lorine Tantalu, dan Gatut Suliana}

Technology of Agroindustry, Agriculture Faculty

University of Tribhuwana Tunggadewi Malang

*E-mail:wirawan@unitri.ac.id

\begin{abstract}
Miscarriage of formalin used as preservative agent for highly perishable commodity was remained problem. Among the fishermen and fish seller tend to use this compound to prolong the commodity to avoid decay. Moreover, great protein for human health is common come from fisheries product. Saponin compound could reduce formaldehyde levels in white shrimp. Cassava leaf var. Malang 1 which abandoned in Malang contains saponin compounds 3,8\% $w / w$. This research used white shrimp which are soaked in formalin solution and then soaked in cassava leaf extract. The experimental design was used a completely randomized design (CRD) with $2 \times 4$ factorials. The experiment used two factors, there are concentration of cassava leaf extract (3\%,6\% and 9\%) which $0 \%$ as control and soaked time (0, 15, 30 and 60 minutes) store in room temperature. The main focus parameter used formaldehyde test by applied formalin test kit. The result showed that by soaked by using cassava leaf extract could reduce began at 0 minutes and more extremely great reducer in 60 minutes in $3 \%$ consentration of cassava leaf extract.
\end{abstract}

Keywords: formalin, fisheries product, saponin, white shrimp

Disubmit : 13 September 2017, Diterima : 01 Desember 2017, Disetujui :08 Desember 2017

\section{PENDAHULUAN}

Kwik Kian Gie (2005) menyebutkan bahwa diperkirakan hasil potensi sumber daya laut di perairan Zona Ekonomi Eksklusif per tahunnya mencapai 6.26 juta ton. Namun demikian, komoditi seperti udang termasuk jenis bahan pangan yang mudah membusuk oleh karena aktivitas metabolisme maupun aktivitas mikroba. Adawyah (2007) menjelaskan bahwa dalam kurun waktu beberapa jam setelah penangkapan hasil laut akan menunjukkan proses perubahan yang mengarah pada kerusakan. Cara umum yang dilakukan untuk mencegah kerusakan tersebut adalah dengan cara pengawetan menggunakan es. Akan tetapi, beberapa dari nelayan maupun penjual mengeluhkan cara ini karena akan dibutuhkan es balok dengan jumlah banyak sehingga menjadi tidak praktis dan relatif lebih mahal. Hal inilah yang menjadi alasan para nelayan atau pedagang untuk mencari alternatif bahan kimia namun ternyata berbahaya bagi manusia yang mengkonsumsi makanan awetan tersebut (Suryadi, dkk., 2010).

Organisasi dunia milik PBB seperti ILO, UNEP, dan WHO telah membentuk lembaga khusus mengenai keselamatan dalam penggunaan bahan kimia yaitu IPCS (International Programme on Chemical Safety). Organisasi ini memaparkan bahwa secara umum ambang batas bahan kimia dalam bentuk cairan yang boleh masuk ke dalam tubuh manusia adalah $1 \mathrm{mg} / \mathrm{Liter}$, dan khusus untuk kadar formalin yang diperbolehkan masuk 
dan tercerna dalam tubuh orang dewasa adalah $1.5 \mathrm{mg}$ hingga $14 \mathrm{mg}$ per hari (Haryati, 2010). perlu adanya upaya untuk dapat mereduksi kadar formalin yang terkandung dalam bahan pangan. Beberapa penelitian telah dilakukan, yaitu dengan memilih bahan pereduksi bahan alami dan mudah ditemukan dilingkungan sekitar. Bahan alami tersebut diantaranya adalah kunyit (Damayanti, et al., 2014), daun kedondong (Dwimayasanti, dkk., 2014), bawang putih (Harningsih dan Susilowati, 2015), lidah buaya (Fadhilah, dkk., 2013), dan lengkuas (Jannah, dkk., 2014).

Syarat utama untuk dapat mereduksi formalin dalam komoditi bahan pangan adalah keberadaan saponin. Daun singkong merupakan salah satu dari bahan alami yang memiliki kandungan saponin sekitar $1-4 \%$ (Wobeto et al, 2007). Singkong varietas Malang 1 merupakan varietas singkong unggulan yang melimpah di Kota Malang (Balitkabi Litbang Pertanian, 2016). Keberadaan yang melimpah tersebut memungkinkan untuk dilakukan pemanfaatan lebih lanjut selain sebagai bahan pokok pangan. Penelitian ini bertujuan untuk memanfaatkan bahan alami daun singkong dengan variasi konsentrasi larutan daun singkong dan lama perendaman yang terbaik untuk mereduksi formalin yang terabsorbsi dalam udang putih.

\section{METODE PENELITIAN}

Bahan yang digunakan dalam penelitian ini adalah udang putih (Penaeus vannamei) yang berasal dari PT. CPB Situbondo dan daun singkong (Manihot esculenta). Larutan untuk perendaman udang putih yaitu formalin $40 \%$ dan aquadest untuk mengencerkan formalin menjadi $5 \%$. Untuk uji kadar air tidak memerlukan bahan kimia tambahan, namun untuk uji kadar formalin ada beberarapa bahan kimia yang harus disiapkan. Bahan kimia tersebut yaitu test kit formalin yang mengandung KMnO4 $1 \mathrm{~N}$ dan aquadest, serta kertas saring untuk menyaring filtrat.

Alat yang digunakan dalam proses perendaman udang putih diantaranya baskom plastiik sebanyak 2 buah. Untuk membuat larutan daun singkong, alat yang digunakan adalah blender dan kain saring untuk memisahkan serat kasar dengan sari daun singkong. Upaya menghancurkan daun singkong dengan blender bertujuan agar dapat mengeluarkan zat saponin yang terkandung didalam daun singkong.

Penelitian akan dilaksanakan selama bulan Maret dan April 2017. Persiapan bahan dilakukan pada minggu pertama bulan Maret. Penelitian laboratorium dan analisa dilakukan pada minggu kedua hingga minggu keempat bulan Maret. Penulisan laporan dilakukan mulai minggu pertama bulan April, dan selanjutnya proses revisi akan dilaksanakan selama minggu kedua dan ketiga bulan April.

Proses persiapan udang putih berformalin, pembuatan larutan daun singkong dan perendaman udang putih didalam larutan daun singkong dilaksanakan di Laboratorium Rekayasa Pangan Universitas Tribhuwana Tunggadewi. Begitu pula untuk pengujian larutan ekstrak daun singkong varietas Malang 1 untuk mereduksi formalin juga dilakukan di laboratorium yang sama. Pengujian kadar saponin pada daun singkong varietas Malang 1 dilakukan di Laboratorium LPPT UGM Yogyakarta.

Langkah - langkah percobaan yang akan dilakukan sesuai dengan diagram alir yang terdapat pada Gambar 1. Rancangan percobaan yang digunakan adalah rancangan acak lengkap (RAL) faktorial dengan faktor konsentrasi larutan daun singkong dan lama rendaman, dengan 4 kali ulangan. Pada tahap ini dilakukan pembuatan larutan formalin 5\%, yaitu larutan formalin $40 \%$ diencerkan menjadi 5\% menggunakan perhitungan M1.V1 = M2.V2. Kemudian larutan ini digunakan untuk merendam udang putih yang didapat dari PT. CPB Situbondo selama 24 jam (Fadhillah, 2016).

Perendaman udang putih dengan larutan daun singkong. Pembuatan larutan daun singkong dengan tiga konsentrasi yaitu 3\% dan 6\% mengikuti standart kimia bahwa persen konsentrasi $1 \%$ berat per volume larutan menyatakan 1 gram dalam $100 \mathrm{~mL}$ pelarut. Untuk konsentrasi akhir rendaman larutan daun singkong sebesar 6\%, maka disiapkan 60 gram daun singkong dan aquadest sebanyak $920 \mathrm{ml}$ dilanjutkan diblender hingga benar-benar hancur. Larutan daun singkong tersebut kemudian disaring dan diharapkan memiliki volume akhir sebesar $980 \mathrm{ml}$. Larutan daun singkong berkonsentrasi $6 \%$ ini digunakan untuk merendam udang 
putih berformalin dengan variasi lama perendaman 0,15 dan 30 menit. Perlakuan yang sama juga dilakukan untuk konsentrasi larutan daun singkong sebesar 3\%. Perbedaanya ada pada berat daun singkong menjadi 30 gram dan jumlah aquadest sebesar $950 \mathrm{ml}$.

Uji kadar Formalin. Uji kadar formalin dilakukan dengan cara menyiapkan sampel udang berformalin pada konsentrasi larutan daun singkong 3\% dan 6\% dengan lama perendaman 0 menit hingga 30 menit sebanyak 5 gram. Larutan test kit formalin yang mengandung KMnO4 1N disiapkan. Sampel udang sebanyak 5 gram dimasukkan kedalam tabung reaksi dan ditambahkan aquadest hingga $10 \mathrm{ml}$. Sampel dihomogenkan dengan pengaduk dan dilanjutkan dengan disaring menggunakan kertas saring. Filtrat yang dihasilkan dimasukan kedalam larutan test kit, dilanjutkan dengan pengamatan perubahan warna. Perubahan warna dari ungu menjadi coklat menunjukkan bahwa formalin telah mengalami reduksi.

\section{HASIL DAN PEMBAHASAN}

Kandungan saponin daun singkong varietas Malang 1. Penentuan kadar saponin pada daun singkong (Manihot esculenta) varietas Malang 1 telah diujikan di Laboratorum LPPT UGM dengan penggunaan kurva Standar Saponin Quilaja bark. Hal yang pertama dilakukan adalah persiapan daun singkong varietas Malang 1 yang diperoleh dari Balitkabi Malang untuk kemudian dihancurkan dengan cara diblender (Gambar 1). Hasil pengujian menunjukkan bahwa daun singkong varietas Malang 1 tersebut mengandung senyawa saponin $0.38383 \mathrm{mg} / 100 \mathrm{~g}$ atau setara dengan $3.8383 \%$ per 100 gram. Telah dikemukakan sebelumnya bahwa secara umum daun singkong memiliki kadar saponin 1-4\% (Wobeto, et al., 2007). Nilai kadar saponin tersebut dapat dinyatakan sedang jika dibandingkan dengan saponin yang dimiliki bahan alami Lidah Buaya (Aloe vera) dengan kadar $5.651 \%$ per 100 gram (Fadhilah, 2013).

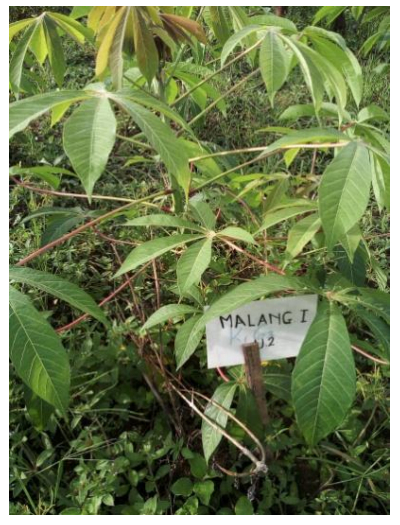

(a)

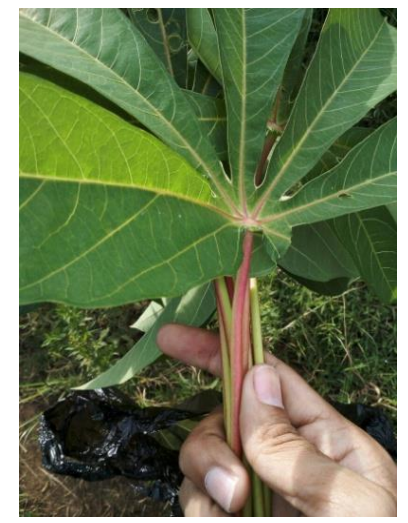

(b)

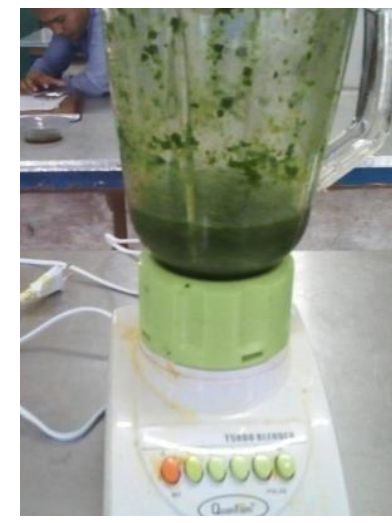

(c)

Gambar 1. Tanaman singkong varietas Malang 1 (a), daun singkong varietas Malang 1 (b), persiapan ekstrak daun singkong

Pengujian udang putih. Dua sampel yang terdiri dari udang putih segar tanpa perendaman formalin dan berformalin diuji dengan menggunakan test kit. Melalui pengamatan perubahan warna dapat diamati bahwa udang putih segar yang diperoleh dari PT CPB Situbondo bebas dari formalin. Warna kuning menandakan tidak adanya formalin, sedangkan warna ungu pada larutan filtrate udang menandakan adanya formalin (Gambar 2). 
Wirawan dkk : Efektivitas Daun Singkong (Manihot esculenta) Var. Malang 1 Sebagai Pereduksi Kadar Formalin...

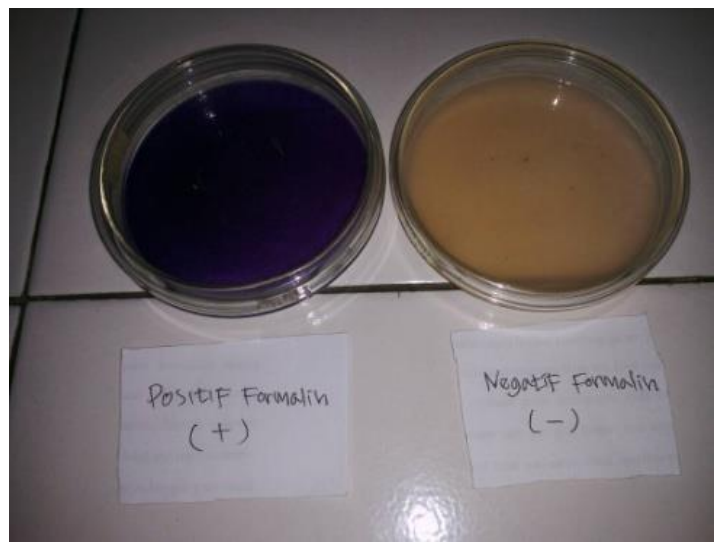

Gambar 2. Pengujian larutan filtrate udang berformalin (a) dan tidak berformalin (b)

Konsentrasi dan lama perendaman terbaik. Penentuan konsentrasi daun singkong varietas Malang 1 untuk mereduksi formalin pada komoditas udang putih merujuk pada penelitian yang dilakukan oleh Dwimayasanti, dkk (2014). Penelitian tersebut menggunakan daun kedondong dengan konsentrasi terbaik terdapat pada 6\%. Untuk itu, penelitian kali ini menggunakan konsentrasi 3\%, 6\% dan 9\% untuk mengetahui perbedaan degradasi warna ungu terendah. Gambar 3. menunjukkan kemampuan varian konsentrasi larutan ekstrak daun singkong dalam mereduksi kadar formalin yang terikat pada udang putih dalam waktu perendaman $0,15,30$ dan 60 menit.

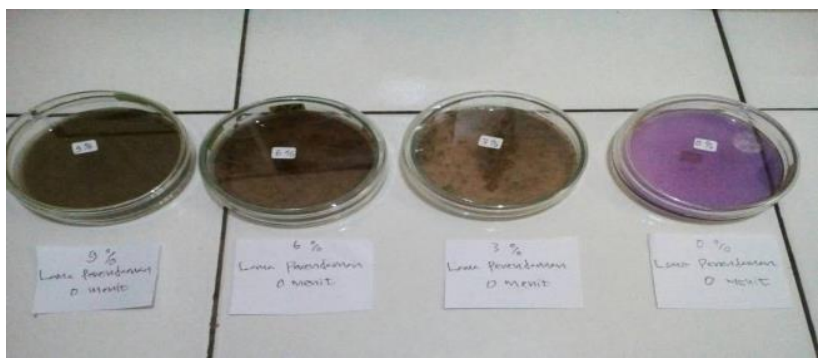

(a)

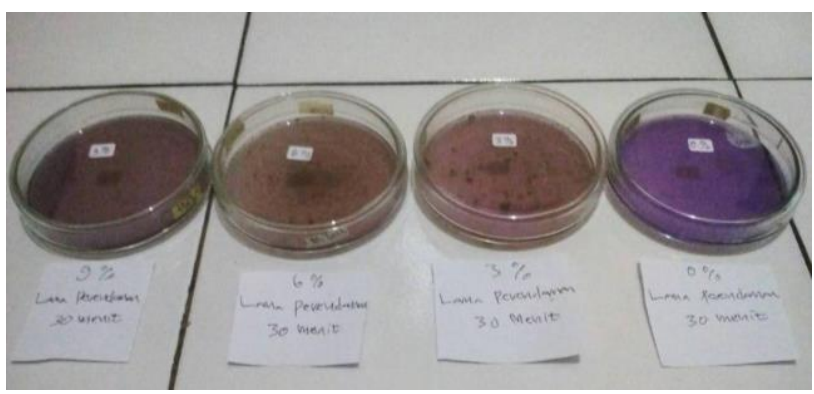

(c)

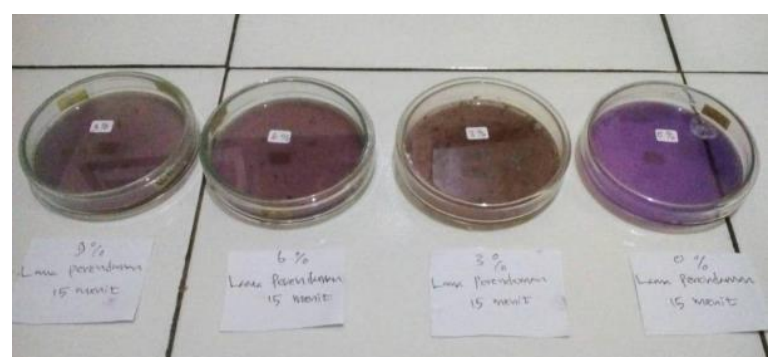

(b)

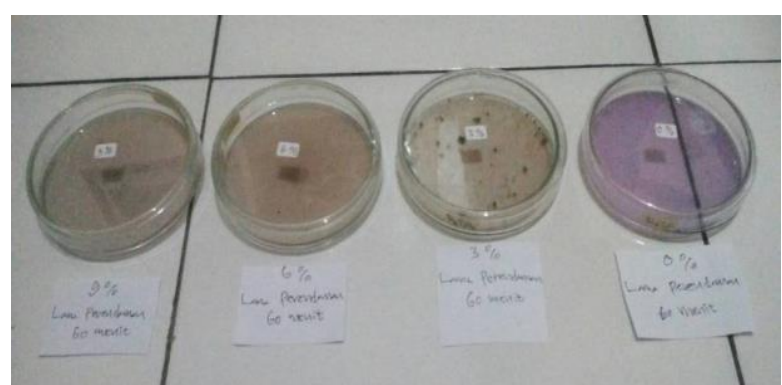

(d)

Gambar 3. Pengamatan perubahan warna untuk konsentrasi ekstrak daun singkong dan lama perendaman 0 menit (a), 15 menit (b), 30 menit (c) dan 60 menit.

Pengamatan perubahan warna pada konsentrasi dan lama perendaman yang berbeda menunjukkan bahwa larutan ekstrak daun singkong efektif dalam mereduksi formalin mulai dari 0 menit atau titik awal permulaan, baik untuk konsentrasi 3\% hingga 9\%. Semakin tinggi konsentrasi ekstrak daun singkong menunjukkan semakin pekatnya warna larutan. Dari pengamatan tersebut juga dapat disimpulkan, walaupun dengan pemaparan dengan larutan ekstrak daun singkong di titik awal sudah mampu mereduksi, namun reduksi 
tersebut tidak berlangsung lama. Berbeda halnya dengan perendaman selama 30 hingga 60 menit yang menunjukan perubahan warna filtrate udang berformalin yang cenderung cerah dan menunjukkan bahwa kadar formalin telah tereduksi Hal ini sesuai dengan penjelasan Rusdiaman (2015), bahwa kinerja metabolit sekunder pada herbal alami bersifat lambat namun bersifat kosntruktif. Tabel 1 menunjukkan kemampuan ekstrak daun singkong dalam mereduksi formalin dalam udang putih.

Tabel 1. Kemampuan ekstrak daun singkong dalam mereduksi formalin pada konsentrasi dan lama perendalam yang berbeda

\begin{tabular}{ccccc}
\hline Perendaman & $0 \%$ & $3 \%$ & $6 \%$ & $9 \%$ \\
Daun Singkong Varietas Malang 1 & -- & + & + & + \\
0 & - & ++ & +++ & +++ \\
35, & - & +++ & +++ & +++ \\
\hline
\end{tabular}

Keterangan: (-) : tidak terjadi reduksi formalin, produk mengandung formalin; $(+)$ : reduksi formalin berjalan cukup baik ; (++) : reduksi formalin berjalan baik; (+++) : reduksi formalin berjalan sangat baik

Mekanisme reduksi kadar formalin pada daging udang putih dijelaskan pada Gambar 4. Kadar formalin pada daging udang putih dapat berkurang oleh adanya paparan senyawa saponin. Senyawa tersebut mampu mengikat partikel formalin untuk larut bersama air. Saponin itu sendiri merupakan bahan sabun (surfaktan) yang memiliki dua gugus polar dan non polar yang dapat menciptakan emulsi. Proses pembentukan emulsi dari senyawa emulgator (bahan aktif permukaan atau surface active agent) tersebut dinamakan saponifikasi (Gusviputri, dkk, 2013). Keberadaan umlgator tersebut mampu menstabilkan busa akibat penurunan tegangan permukaan pada air.

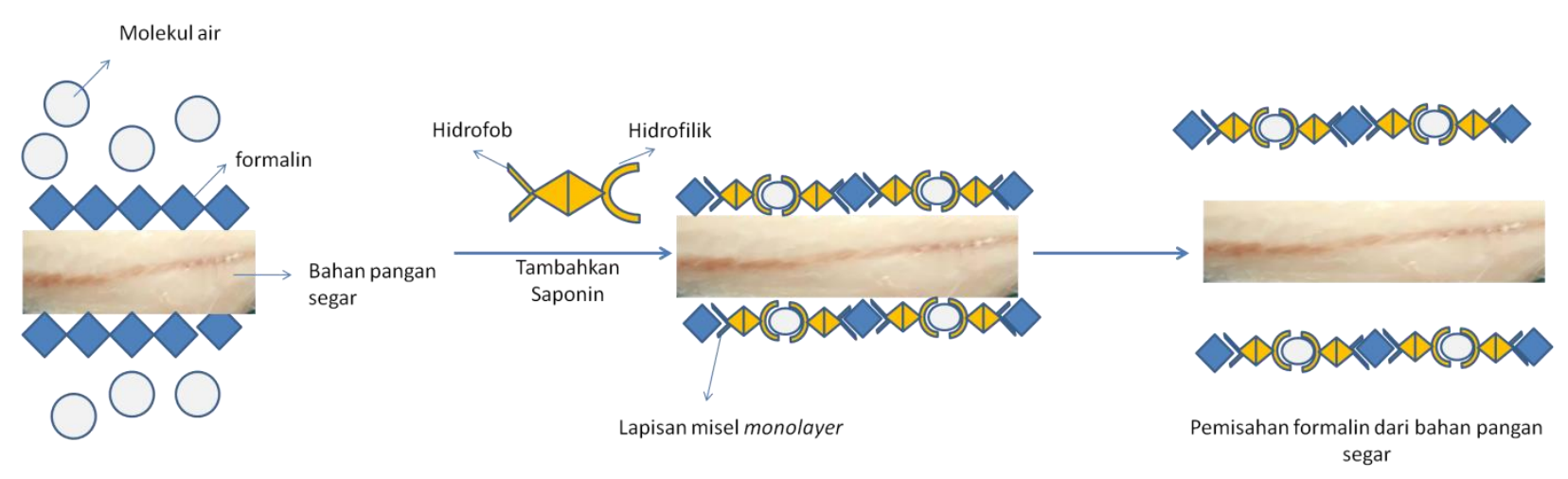

Gambar 4. Mekanisme reduksi formalin dengan menggunakan senyawa saponin

Menurut Dwimayasanti (2014), formalin yang terikat pada produk dapat terlepas oleh adanya kontribusi gugus polar (hidrofilik) dan non polar (hidrofobik) pada zat surfaktan senyawa saponin. Zat tersebut teradsorbsi ke daerah antar fase dan mengikat partikel formalin sehingga kestabilan emulsi didapat dari gugus polar.

\section{KESIMPULAN DAN SARAN}

Formalin merupakan bahan kimia yang berbahaya jika dikonsumsi oleh tubuh dalam dosis yang cukup tinggi. Melalui perendaman dengan larutan ekstrak daun singkong secara efektif mampu mereduksi kadar formalin pada bahan pangan segar seperti halnya pada udang putih dikarenakan keberadaan senyawa saponin. Penelitian ini perlu adanya pengujian parameter lain yang mempengaruhi organoleptik dari bahan pangan segar untuk kegiatan konsumsi selanjutnya. 
Wirawan dkk : Efektivitas Daun Singkong (Manihot esculenta) Var. Malang 1 Sebagai Pereduksi Kadar Formalin...

\section{UCAPAN TERIMA KASIH}

Terima kasih kepada DRPM DIKTI yang telah membiayai penelitian ini pada skim Penelitian Dosen Pemula (PDP) dan Universitas Tribhuwana Tunggadewi Malang.

\section{DAFTAR PUSTAKA}

Adawyah, R. 2007. Pengolahan dan Pengawetan Ikan. Penerbit Bumi Aksara. Jakarta

Balitkabi Litbang Pertanian. 2016. Pangan Sehat dan Cantik dari Ubi. http://balitkabi.litbang.pertanian.go.id/. [akses tanggal 31 Juli 2017].

Damayanti, E., W.F. Ma'ruf, dan I. Wijayanti. 2014. Efektivitas Kunyit (Curcuma lunga Linn) Sebagai Pereduksi Formalin pada Udang Putih (Penaeus merguensis) Penyimpanan suhu dingin. Jurnal Pengolahan dan Bioteknologi Hasil Perikanan. Vol 3. No. 1. pp. 98 - 107

Dwimayasanti, R. W.F. Ma'ruf dan P.H. Riyadi. 2014. Efektivitas Larutan Daun Kedondong (Spondias sp.) Sebagai Pereduksi Kadar Formalin Pada Fillet Ikan Bandeng (Chanos chanos Forsk) Selama Penyimpanan Dingin. Jurnal Pengolahan dan Bioteknologi Hasil Perikanan. Vol. 3. No. 2. pp. $44-51$

Fadhilah, A.P., W.F. Ma'ruf, dan L. Rianingsih. 2013. Efektivitas lidah buaya (Aloe vera) Didalam Mereduksi Formalin Pada Fillet Ikan Bandeng (Chanos chanos Forsk) Selama Penyimpanan Suhu Dingin. Jurnal Pengolahan dan Bioteknologi Hasil Perikanan. Vol. 2. No. 3. pp. 21 - 30.

Gie,K.K. 2005. Mengatasi Bencana Ekonomi Nasional. Dalam HMT Oosunggu. Jakarta. LKSN

Gunawan, D dan Mulyani S. 2004. Ilmu Obat Alam (Farmakognasi). Jilid I. Penerbit Swadaya. Jakarta

Gusviputri, A., NjooMeliana P.S., Aylianawati, dan Nani I. 2013. Pembuatan Sabun dengan Lidah Buaya (Aloe vera) Sebagai Antiseptik Alami. Jurnal Widya Teknik Surabaya Vol.12, No. 1

Harningsih, T dan I.T. Susilowati. 2015. Metode Reduksi Tahu Berformalin Menggunakan Varian Konsentrasi Air Garam yang Ditambahkan dengan Ekstrak Bawang Putih (Allium satiuvum L.). Jurnal KesMaDaSka.

Jannah, M. W.F. Ma'ruf dan T. Surti. 2014. Efektivitas Lengkuas (Alpinia galonga) Sebagai Pereduksi Kadar Formalin Pada Udang Putih (Penaeus merguensis) Selama Penyimpanan Dingin. Jurnal Pengolahan dan Bioteknologi Hasil Perikanan. Vol. 3. No. 1. pp. $70-79$

Suryadi, H., M. Kurniadi, dan Y. Melanie. 2010. Analisis Formalin Dalam Sampel Ikan dan Udang Segar dari Pasar Muara Angke. Majalah Ilmu Kefarmasian. Vil. VIII. No. 3. pp. 16 - 31. 